\title{
Association of oral dysbiosis with oral cancer development (Review)
}

\author{
GIUSY RITA MARIA LA ROSA ${ }^{1,2}$, GIUSEPPE GATTUSO ${ }^{2,3}$, EUGENIO PEDULLÀ ${ }^{1}$, \\ ERNESTO RAPISARDA ${ }^{1}$, DARIA NICOLOSI ${ }^{3 *}$ and MARIO SALMERI ${ }^{3,4^{*}}$
}

\author{
${ }^{1}$ Department of General Surgery and Surgical-Medical Specialties, University of Catania, I-95125 Catania; \\ ${ }^{2}$ Department of Biomedical and Biotechnological Sciences, International PhD Program in Basic and Applied Biomedical \\ Sciences; ${ }^{3}$ Department of Biomedical and Biotechnological Sciences, ${ }^{4}$ Department of Biomedical and Biotechnological \\ Sciences, Research Center for Prevention, Diagnosis and Treatment of Cancer, University of Catania, I-95123 Catania, Italy
}

Received October 28, 2019; Accepted December 4, 2019

DOI: $10.3892 / \mathrm{ol} .2020 .11441$

\begin{abstract}
Oral squamous cell carcinoma (OSCC) is the leading cause of mortality for oral cancer. Numerous risk factors mainly related to unhealthy habits and responsible for chronic inflammation and infections have been recognized as predisposing factors for oral carcinogenesis. Recently, even microbiota alterations have been associated with the development of human cancers. In particular, some specific bacterial strains have been recognized and strongly associated with oral cancer development (Capnocytophaga gingivalis, Fusobacterium spp., Streptococcus spp., Peptostreptococcus spp., Porphyromonas gingivalis and Prevotella spp.). Several hypotheses have been proposed to explain how the oral microbiota could be involved in cancer pathogenesis by mainly paying attention to chronic inflammation, microbial synthesis of cancerogenic substances, and alteration of epithelial barrier integrity. Based on knowledge of the carcinogenic effects of dysbiosis, it was recently suggested that probiotics may have anti-tumoral activity. Nevertheless, few data exist with regard to probiotic effects on oral cancer. On this basis, the association between the development of oral cancer and oral dysbiosis is discussed focusing attention on the potential benefits of probiotics administration in cancer prevention.
\end{abstract}

\section{Contents}

1. Introduction

2. Impact of oral health dysregulation on oral cancer development

Correspondence to: Dr Mario Salmeri, Department of Biomedical and Biotechnological Sciences, University of Catania, Via Santa Sofia 97, I-95123 Catania, Italy

E-mail:m.salmeri@unict.it

${ }^{*}$ Contributed equally

Key words: microbiota, microbiome, oral cancer, carcinogenesis, chronic inflammation, dysbiosis, oral squamous cell carcinoma, probiotics
3. Possible mechanisms of carcinogenesis induced by dysbiosis

4. Oral bacteria with potential carcinogenetic activity

5. Anti-tumoral effects of probiotics

6. Conclusions

\section{Introduction}

Oral squamous cell carcinoma (OSCC) is the leading cause of death among all oral cancers. This tumor originates from the oral mucosa and accounted for over 350,000 new diagnoses and more than 175,000 recorded deaths worldwide in 2018 (1). It was widely demonstrated that the development of tumors, including that of OSCC, is sustained by several risk factors and predisposing conditions such as fibers, chemicals, pesticides and heavy metals able to induce pro-oncogenic genetic and epigenetic alterations (2-6). Other factors, including oral injuries, inflammatory diseases, infections, and bacterial dysbiosis are now recognized as risk factors for cancer development (7-10).

Regarding OSCC, it was demonstrated that its development is strictly influenced by host-related and lifestyle factors mainly represented by smoking, alcohol abuse, tobacco and tobaccoderivate chewing and oral virus infections (HPV) $(11,12)$. In addition, it was demonstrated that the combination of smoke, alcohol drinking and poor oral hygiene increase the risk of oral cancer onset due to chronic inflammation and infection which constitute the principal factors involved in cancer pathogenesis, influencing the resident microbiota that are involved in the homeostasis of the oral environment (13-17). Importantly, a precise distinction must be made between microbiota and microbiome: the former is comprised of all the bacteria species hosted within the oral cavity, while with the latter term is used to define the collective genomes of microorganisms inhabiting the oral mucosa (18-20).

Oral microbiota changes are able to modulate the connection between oral bacteria and humans causing diseases $(21,22)$. Oral microbiota seems to influence OSCC through the carcinogenetic modulation of cell metabolism (such as modifying the concentration of nutrients and vitamins), thereby promoting the production of different cytokines known to be involved in several pathological conditions (23-27). 
Over 600 bacterial species constitute the oral microbiota. However, the majority of these species are uncultivated (19). The availability of new sequencing technology allowed the identification of bacterial communities that harbor the oral cavity and that are involved in human health (28) (Table I).

Researchers have investigated the possible association between microbes and the alteration of physiological conditions. In this context, it was demonstrated that gut microbiota predisposes individuals for the development of different diseases including celiac disease, neurological disorders and blood pressure alterations (29-31). All these pathological conditions are involved in the development of severe health conditions mainly represented by neurovascular disorders, chronic degenerative diseases, and cancer (32-46). Among all cancers, oral cancer is particularly related with oral and gut microbiota composition as widely demonstrated. Among the different bacteria strongly associated with OSCC, Fusobacterium nucleatum, Porphyromonas gingivalis, and Prevotella intermedia are considered the most represented bacteria types (47-51). Moreover, other bacterial genera, such as Actinomyces, Clostridium, Enterobacteriaceae, Fusobacterium, Haemophilus, Porphyromonas, Prevotella, Streptococcus spp. and Veillonella are associated with pre-cancerous lesions and oral cancer (52). According to other studies, a high bacterial load of Prevotella melaninogenica, Streptococcus mitis and Capnocytophaga gingivalis are identifiable in saliva samples of OSCC patients (Table II) $(50,51)$.

Although the association between some species and oral cancer was already established, the complexity of the relationship occurring between cancer and oral microbiota remains unexplained and cannot be limited to the evaluation of a single pathogen (53). Moreover, there are no concordant analytical protocols for the analysis of oral microbiota and microbiome. Therefore, it is difficult to establish oral cavity-associated microbial patterns in cancer patients and healthy subjects. Consequently, there is a lack of novel microbial biomarkers for the early identification of oral carcinoma $(54,55)$.

Previous findings demonstrated that a strong association between oral microbiota and oral cancer exists. Starting from this supposition, a number of studies focused on the prevention of neoplastic transformation and retardation of cancer progression by modulating the carcinogenic or protective microbiome. In this context, probiotics administration was recently considered a good cancer preventive strategy due to the immunological effects $(8,9,25)$. The beneficial effects of lactic ferments and probiotics were identified in the 19th century by Dr Ilya Metchnikoff. Nevertheless, only in recent years have these products been widely used for the treatment of several diseases $(56,57)$. Numerous studies have shown the potential positive effects of probiotics on cancer through several mechanisms that include immune modulation, the prevention of pathogen infections, inflammatory modulation, reduced cancer formation and metastatic process $(9,25)$. To the best of our knowledge, few data have been generated about the effects of probiotics in oral cancer development. Of note, the results of a previous study demonstrated that the administration of Lactobacillus rhamnosus GG (LGG) was able to increase the effects of geniposide, an anticancer molecule tested on human oral squamous carcinoma cells (HSC-3), demonstrating the beneficial role of LGG as potential adjuvant of geniposide treatment (58).

The aim of this review was to describe the scientific evidence collected during the years pertaining to oral microbiota and neoplastic transformation with special attention for OSCC. Finally, a brief overview on the anti-tumoral effect of probiotics and their applications in oral cancer was reported.

\section{Impact of oral health dysregulation on oral cancer development}

Observational studies have shown a link among oral cancer and infrequent tooth brushing, infrequent dental visits and loss of or missing teeth (59-62). These findings, however, pertain only to non-smokers and non-drinkers (13-14). Another study revealed that periodontal illnesses are correlated with an increased risk for oral tumors (63). Furthermore, research performed on 51 tongue cancer patients and 54 normal controls cases revealed that chronic periodontal inflammation is a cancer risk factor (64). In addition, periodontitis patients showed an increased risk for OSCC compared to healthy controls (65). Another observational study conducted on a wide cohort of individuals in the USA investigated the use of dental care and oral cancer risk. The analysis of covariates and dental care appointments demonstrated that individuals with a dental appointment during the past 12 months had a lower (62\%) oral cancer risk compared with subjects that had not used dental care procedures in the past year (66).

According to these results, the research group of Börnigen et al (67) analyzed the role of oral microbiome and its composition by analyzing the biological samples of 121 oral cancer patients and 242 healthy controls matched for age and sex. The multivariate analyses highlighted significant variations of the oral microbiome in subjects with poor dental hygiene, in smokers, and oral cancer patients. In particular, although the microbiome alterations in cancer patients were significant, the alterations were more evident after tooth loss. Therefore, findings of that study showed that both oral microbiome alterations and tooth loss constitute important risk factors for oral cancer development due to the molecular and microenvironmental changes occurring in the oral cavity after these events (67).

\section{Possible mechanisms of carcinogenesis induced by dysbiosis}

The association between gut microbiota and gastric cancer is well known (68). However, the association between oral cancer and oral dysbiosis is not fully understood (69). Different mechanisms of action to elucidate the oral microbiota influence on cancer pathogenesis, including bacterial stimulation of chronic inflammation have been reported. This process causes the production of inflammatory mediators that can cause or facilitate mutagenesis, uncontrolled cell proliferation, angiogenesis and cell degeneration responsible for neurodegenerative disorders and cancer (70-72). In addition, bacteria are able to modulate cell proliferation through activation of the nuclear factor $\kappa \mathrm{B}(\mathrm{NF}-\kappa \mathrm{B})$ and the inhibition of cell apoptosis 
Table I. Most common microbial species represented in a normal bacterial flora of oral cavity.

\begin{tabular}{|c|c|c|c|}
\hline Bacterial species & Characteristics & Localization & Distribution \\
\hline Streptococcus mitis & $\begin{array}{l}\text { Gram-positive coccus, } \\
\text { facultative anaerobe. } \\
\text { It has been associated with: } \\
\text { i) Bacterial endocarditis, especially in } \\
\text { patients with prosthetic valves; } \\
\text { ii) Infection in immunocompromised } \\
\text { patients, particularly immediately after } \\
\text { tissue transplants and in neutropenic } \\
\text { cancer patients. }\end{array}$ & $\begin{array}{c}\text { Buccal surface } \\
\text { Vestibule } \\
\text { Tongue } \\
\text { Palate } \\
\text { Tonsils } \\
\text { Tooth surfaces } \\
\text { Subgingival surface }\end{array}$ & $\begin{array}{l}\text { High } \\
\text { High } \\
\text { High } \\
\text { High } \\
\text { High } \\
\text { High } \\
\text { High }\end{array}$ \\
\hline $\begin{array}{l}\text { Streptococcus } \\
\text { sanguis }\end{array}$ & $\begin{array}{l}\text { Gram-positive coccus, } \\
\text { facultative anaerobe. } \\
\text { It has been associated with: } \\
\text { i) Bacterial endocarditis, especially in } \\
\text { patients with prosthetic valves; } \\
\text { ii) Infection in immunocompromised } \\
\text { patients. }\end{array}$ & $\begin{array}{c}\text { Buccal surface } \\
\text { Tongue lateral } \\
\text { Palate } \\
\text { Tooth surfaces } \\
\text { Subgingival surface }\end{array}$ & $\begin{array}{l}\text { Medium } \\
\text { Medium } \\
\text { Medium } \\
\text { High } \\
\text { Medium }\end{array}$ \\
\hline $\begin{array}{l}\text { Streptococcus } \\
\text { gordonii }\end{array}$ & $\begin{array}{l}\text { Gram-positive coccus, } \\
\text { facultative anaerobe. } \\
\text { It has been associated with: } \\
\text { i) Bacterial endocarditis, especially in } \\
\text { patients with prosthetic valves; } \\
\text { ii) Infection in immunocompromised } \\
\text { patients. }\end{array}$ & $\begin{array}{c}\text { Buccal surface } \\
\text { Vestibule } \\
\text { Palate } \\
\text { Tooth surfaces } \\
\text { Subgingival surface }\end{array}$ & $\begin{array}{l}\text { Medium } \\
\text { Medium } \\
\text { Medium } \\
\text { High } \\
\text { Medium }\end{array}$ \\
\hline Gemella sanguinis & $\begin{array}{l}\text { Gram-positive coccus, } \\
\text { facultative anaerobe. } \\
\text { It has been associated with: } \\
\text { i) Bacterial endocarditis. }\end{array}$ & $\begin{array}{l}\text { Buccal surface } \\
\text { Vestibule } \\
\text { Tongue lateral } \\
\text { Palate }\end{array}$ & $\begin{array}{l}\text { High } \\
\text { High } \\
\text { High } \\
\text { High }\end{array}$ \\
\hline $\begin{array}{l}\text { Gemella } \\
\text { haemolysans }\end{array}$ & $\begin{array}{l}\text { Gram-positive coccus, } \\
\text { facultative anaerobe. } \\
\text { It has been associated with: } \\
\text { i) Bacterial endocarditis. }\end{array}$ & $\begin{array}{c}\text { Tonsils } \\
\text { Tooth surfaces } \\
\text { Subgingival surface }\end{array}$ & $\begin{array}{l}\text { High } \\
\text { High } \\
\text { Medium }\end{array}$ \\
\hline $\begin{array}{l}\text { Granulicatella } \\
\text { elegans }\end{array}$ & $\begin{array}{l}\text { Gram-positive coccus, } \\
\text { facultative anaerobe. } \\
\text { It has been associated with: } \\
\text { i) Infective endocarditis. }\end{array}$ & $\begin{array}{l}\text { Buccal surface } \\
\text { Vestibule } \\
\text { Tongue lateral } \\
\text { Hard palate } \\
\text { Soft palate } \\
\text { Tonsils } \\
\text { Subgingival surface }\end{array}$ & $\begin{array}{l}\text { Medium } \\
\text { High } \\
\text { Medium } \\
\text { High } \\
\text { Medium } \\
\text { Medium } \\
\text { Medium }\end{array}$ \\
\hline $\begin{array}{l}\text { Granulicatella } \\
\text { adiacens }\end{array}$ & $\begin{array}{l}\text { Gram-positive coccus, } \\
\text { facultative anaerobe. } \\
\text { It has been associated with: } \\
\text { i) Infective endocarditis. }\end{array}$ & $\begin{array}{c}\text { Buccal surface } \\
\text { Vestibule } \\
\text { Tongue } \\
\text { Hard palate } \\
\text { Soft palate } \\
\text { Tooth surfaces } \\
\text { Subgingival surface }\end{array}$ & $\begin{array}{l}\text { High } \\
\text { Medium } \\
\text { High } \\
\text { Medium } \\
\text { High } \\
\text { High } \\
\text { Medium }\end{array}$ \\
\hline Neisseria spp. & $\begin{array}{l}\text { Gram-negative diplococci, } \\
\text { aerobic. } \\
\text { Most gonococcal infections are } \\
\text { asymptomatic and self-resolving } \\
\text { except for } N . \text { meningitidis and }\end{array}$ & $\begin{array}{l}\text { Buccal surface } \\
\text { Tongue } \\
\text { Palate } \\
\text { Tonsils } \\
\text { Tooth surfaces }\end{array}$ & $\begin{array}{l}\text { Medium } \\
\text { Medium } \\
\text { High } \\
\text { Medium } \\
\text { High }\end{array}$ \\
\hline
\end{tabular}


Table I (Continued). Most common microbial species represented in a normal bacterial flora of oral cavity.

\begin{tabular}{llcc}
\hline Bacterial species & \multicolumn{1}{c}{ Characteristics } & Localization & Distribution \\
\hline Streptococcus mitis & Gram-negative rod-shaped bacteria, & Buccal surface & Medium \\
& anaerobic. & Tongue & Medium \\
& It is a fundamental human pathogen & Soft palate & Medium \\
& in various anaerobic infections & Tonsils & Medium \\
& (i.e. transmissible subcutaneous & Tooth surfaces & Medium \\
& infections). & Subgingival surface & Medium \\
\hline
\end{tabular}

${ }^{\mathrm{a} M i c r o b i a l ~ s p e c i e s ~ a s ~ i n d i c a t e d ~(205) . ~}$

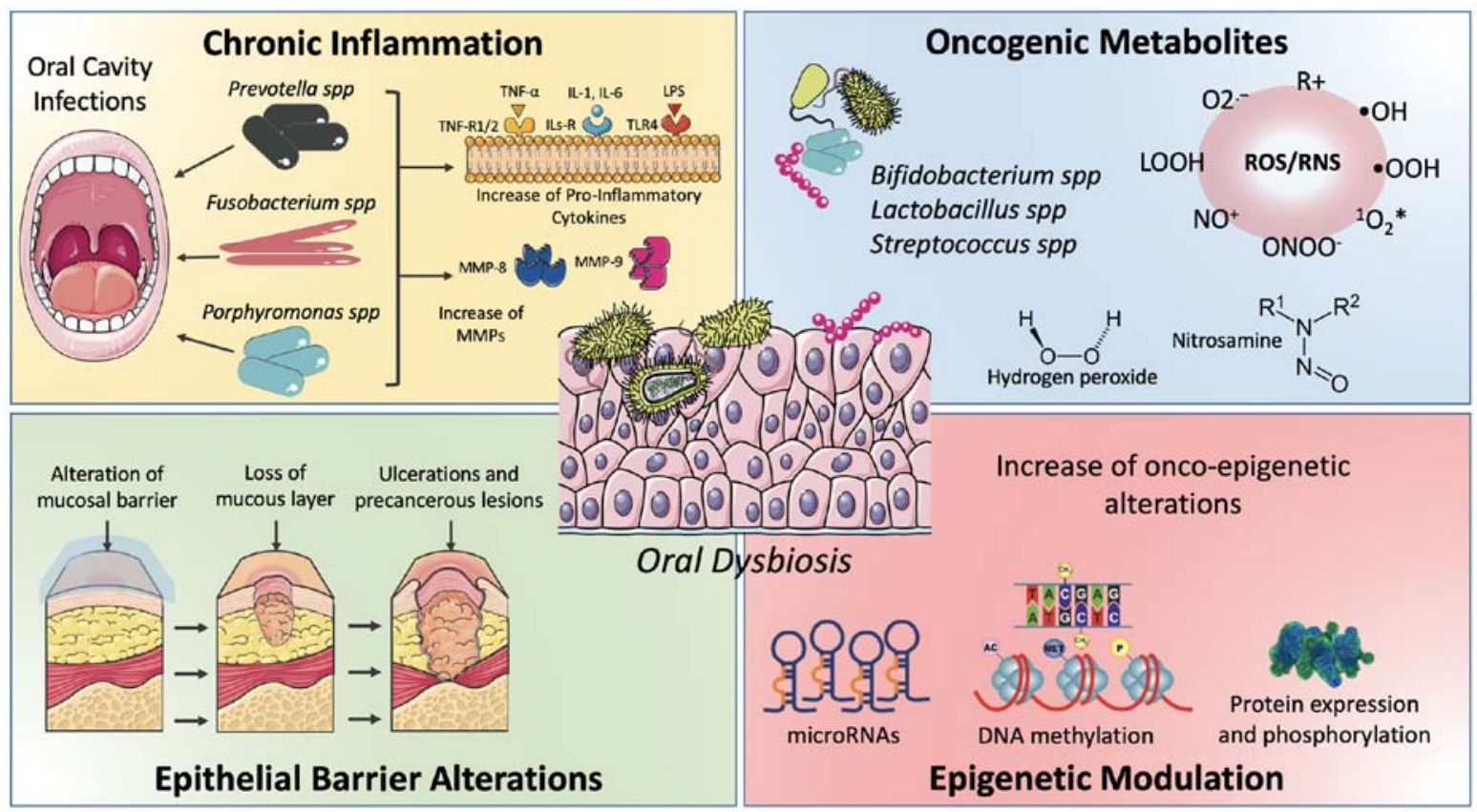

Figure 1. Oral microbiota dysbiosis is associated with oral cancer development through different mechanisms. Oral infections and dysbiosis are responsible for the instauration of a pro-inflammatory microenvironment of which inflammatory cytokines and matrix metalloproteinases favor the development and progression of tumors. Furthermore, the bacteria host in the oral cavity produces oxygen and nitrogen reactive species, as well as oncogenic metabolites (e.g., nitrosamines) to induce genetic damage to cells composing the oral mucosa. Another mechanism of neoplastic transformation mediated by oral dysbiosis is the alteration of the epithelial barriers predisposing the individuals for the development of chronic pre-cancerous lesions. Finally, oral dysbiosis is responsible for several epigenetic alterations predisposing the development of tumors (e.g., alteration of onco-miR or DNA methylation phenomena).

promoting or inhibiting the development of several cancer types (73-75).

Moreover, Pang et al specified that the integration of virus oncogenes into host genomes or the alteration of epithelial barrier integrity could promote genome instability and favor irreversible cellular damage (76). In this context, it is noteworthy that the complex interaction among microbiota, epithelial barriers, and inflammation could assume a key role in the carcinogenic process (77-80).

Finally, it was recently demonstrated that microbiota and oral mucosa dysbiosis lead to the accumulation of different epigenetic alterations predisposing for neoplastic transformation (Fig. 1) (81).

Chronic inflammation. According to data reported in the literature, approximately $25 \%$ of human cancer shares chronic inflammation as a risk factor, indicating that inflammation is one of the most important hallmarks of cancer (82). Several processes including cell proliferation, angiogenesis, mutagenesis and oncogene activation may be caused or facilitated by chronic inflammatory mediators that alter the normal homeostasis of cells and tissues (82).

Some anaerobic oral bacteria including Fusobacterium, Porphyromonas and Prevotella species are associated with periodontal diseases and lead to chronic inflammation. The inflammatory mediators secreted by bacterial cells are able to interact with the cells of different tissues inducing diffused inflammatory processes. Periodontal bacteria influence the paracrine production of different pro-inflammatory mediators, such as interleukins (IL-1, IL-6, IL-17, IL-23), tumor-necrosis factor- $\alpha$ (TNF- $\alpha$ ), and proteinases able to deteriorate the extracellular matrix (MMP-8, -9 and -13) $(83,84)$. The increased 
Table II. Predominant microbial communities associated with OSCC.

\begin{tabular}{|c|c|c|c|}
\hline Bacterial species & Localization (206) & Refs. & Type of sample \\
\hline Actinomyces spp & Tooth surface & $(52)$ & Saliva samples \\
\hline Bacteroides spp & Gingival crevice & $(110,111,187)$ & Saliva samples \\
\hline Bifidobacterium spp & Tooth surface & $(112,113)$ & Plaque biofilm samples \\
\hline Capnocytophaga spp & $\begin{array}{c}\text { Gingival crevice } \\
\text { Tongue }\end{array}$ & $\begin{array}{c}(49) \\
(50) \\
(51) \\
(53) \\
(117) \\
(181-184)\end{array}$ & $\begin{array}{c}\text { Samples of gingival SCC } \\
\text { and normal gingiva } \\
\text { Oral rinse } \\
\text { Saliva samples } \\
\text { Oral swabs } \\
\text { Oral rinse } \\
\text { Samples of oral tumour and } \\
\text { precancerous leukoplakia } \\
\text { Samples of tongue and floor } \\
\text { SCC and normal tissues }\end{array}$ \\
\hline Catonella spp & Gingival crevice & $(175)$ & Oral swabs \\
\hline Clostridium spp & Gingival crevice & $(52)$ & Saliva samples \\
\hline Dialister spp & Gingival crevice & $(175)$ & Oral swabs \\
\hline Enterobacteriaceae spp & Gingival crevice & $(52)$ & Saliva samples \\
\hline Enterococcus spp & Tongue, tooth surface & (53) & Saliva samples \\
\hline Filifactor spp & Gingival crevice & $(175)$ & Oral swabs \\
\hline Firmicutes spp & Gingival crevice & $(187)$ & Saliva samples \\
\hline Fusobacteria spp & Gingival crevice & $\begin{array}{l}(51) \\
(117) \\
(175) \\
(176) \\
(180)\end{array}$ & $\begin{array}{c}\text { Saliva samples } \\
\text { Oral swabs } \\
\text { OSCC biopsies and deep- } \\
\text { epithelium swabs } \\
\text { Oral rinse }\end{array}$ \\
\hline Haemophilus spp & $\begin{array}{l}\text { Oropharynx } \\
\text { Tonsil }\end{array}$ & $\begin{array}{l}(52) \\
(181)\end{array}$ & $\begin{array}{c}\text { Saliva samples } \\
\text { Oral rinse }\end{array}$ \\
\hline Lactobacillus spp & Tooth surface & $(112,113)$ & Plaque biofilm samples \\
\hline Lactococcus spp & Tooth surface & $(112,113)$ & Plaque biofilm samples \\
\hline Leuconostoc spp & Tooth surface & $(112,113)$ & Plaque biofilm samples \\
\hline Oribacterium spp & $\begin{array}{l}\text { Gingival crevice } \\
\text { Tooth surface }\end{array}$ & (181) & Oral rinse \\
\hline Paludibacter spp & $\begin{array}{l}\text { Gingival crevice } \\
\text { Tooth surface }\end{array}$ & $(181)$ & Oral rinse \\
\hline Parvimonas spp & $\begin{array}{l}\text { Gingival crevice } \\
\text { Tooth surface }\end{array}$ & $\begin{array}{l}(53) \\
(175)\end{array}$ & $\begin{array}{l}\text { Saliva samples } \\
\text { Oral swabs }\end{array}$ \\
\hline Pediococcus spp & Tooth surface & $(112,113)$ & Plaque biofilm samples \\
\hline
\end{tabular}


Table II (Continued). Predominant microbial communities associated to OSCC.

\begin{tabular}{|c|c|c|c|}
\hline Bacterial species & Localization (206) & Refs. & Type of sample \\
\hline Peptococcus spp & Gingival crevice & $(175)$ & Oral swabs \\
\hline Peptostreptococcus spp & $\begin{array}{c}\text { Tooth surface } \\
\text { Gingival crevice }\end{array}$ & $\begin{array}{l}(51) \\
(53) \\
(90) \\
(114) \\
(175) \\
(183) \\
(184)\end{array}$ & $\begin{array}{c}\text { Saliva samples } \\
\text { Samples of dental abscess, } \\
\text { endodontic or pericoronal } \\
\text { infection, periodontal pocket } \\
\text { Oral swabs } \\
\text { Samples of tongue and floor } \\
\text { SCC and normal tissues }\end{array}$ \\
\hline Porphyromonas gingivalis & $\begin{array}{c}\text { Tongue } \\
\text { Gingival crevice }\end{array}$ & $\begin{array}{c}(47-49) \\
(51,53) \\
(90) \\
(183) \\
(184)\end{array}$ & $\begin{array}{c}\text { Samples of gingival SCC } \\
\text { and normal gingiva } \\
\text { Saliva samples } \\
\text { Samples of tongue and floor } \\
\text { SCC and normal tissues }\end{array}$ \\
\hline Prevotella intermedia & Gingival crevice & $\begin{array}{c}(50,51) \\
(90)\end{array}$ & $\begin{array}{c}\text { Oral rinse } \\
\text { Saliva samples }\end{array}$ \\
\hline Rothia spp & $\begin{array}{l}\text { Gingival crevice } \\
\text { Tooth surface }\end{array}$ & $(122)$ & Oral rinse \\
\hline Slackia spp & Gingival crevice & $(53)$ & Saliva samples \\
\hline Streptococcus spp & $\begin{array}{l}\text { Gingival crevice } \\
\text { Oropharynx } \\
\text { Tooth surface } \\
\text { Tonsil } \\
\text { Gingival crevice } \\
\text { Oropharynx } \\
\text { Tooth Surface } \\
\text { Tonsil }\end{array}$ & $\begin{array}{l}(50) \\
(51) \\
(52) \\
(90) \\
(122) \\
(124) \\
(125) \\
(182)\end{array}$ & $\begin{array}{c}\text { Oral rinse } \\
\text { Saliva samples } \\
\text { Samples of oral tumour and } \\
\text { precancerous leukoplakia }\end{array}$ \\
\hline
\end{tabular}

production of these inflammatory proteins is responsible for several types of cancer and the overexpression of these proteins (especially IL-6 and MMP-9) predict for a worse prognosis and an aggressive tumor phenotype (85-87).

The upregulation of cytokines and other inflammatory factors lead to the alteration of different molecular pathways, including metabolic pathways, responsible for the modulation of cell metabolism and proliferation. For example, RAGE protein expression changes significantly after periodontal diseases mediated by oral microbiota alterations, leading to carcinogenesis (88). Moreover, gram-negative bacteria release a pro-inflammatory lipopolysaccharide endotoxin (LPS) able to stimulate the production of IL1- $\beta$, IL- 6 ant TNF- $\alpha$ by binding the TLR receptor of leucocytes $(89,90)$. In particular, these inflammatory cytokines lead to the overexpression of other proinflammatory proteins stimulating the release of phospholipase A2, prostaglandins (PG) and acute phase proteins $(91,92)$. Other studies demonstrated that high IL-1 levels favor a pro-angiogenetic microenvironment, supporting tumor spread (93-95). Simultaneously, IL-1 induces MMP-9, which has been associ- ated with more aggressive phenotypes of carcinoma, higher invasiveness, and low patient survival $(96,97)$.

Other studies demonstrated that tumor spread is also sustained by the overexpression of IL-6, which in turn leads to the upregulation of matrix-metalloproteinases, adhesion molecules and endothelial leukocyte adhesion molecules $(98,99)$. All these data showed that interleukins, and in particular IL-6, are strictly involved in neoplastic transformation (100). Besides interleukins, altered levels of TNF- $\alpha$, mediated by the alteration of $\mathrm{Wnt}$ and $\mathrm{NF}-\kappa \mathrm{B}$ pathways, were associated with the development of tumors $(101,102)$. These data further corroborate the importance of $\mathrm{NF}-\kappa \mathrm{B}$ in cancer. Indeed, $\mathrm{NF}-\kappa \mathrm{B}$ acts as an immunostimulant factor against neoplastic cells; however, its protein expression is increased in several cancers acting as an oncogene $(103,104)$.

The abovementioned evidence suggested that dysbiosisassociated cancer may rely on the abnormal activation of $\mathrm{NF}-\kappa \mathrm{B}(68)$. Thus, a fundamental role is played also by the immune system, which in the presence of pathogens stimulates the production of $\mathrm{NF}-\kappa \mathrm{B}(105)$. 
Oncogenic substances production. Numerous substances produced by bacteria have been suggested to possess a carcinogenic action. Bacterial metabolism leads to the production of sulfur compounds, acids and free radicals, mainly nitric and oxygen reactive species, able to induce pro-tumoral genetic damage. Furthermore, several bacteria have an alcoholic metabolism responsible for the production of acetaldehyde, which sustains neoplastic transformation (90).

Regarding reactive oxygen species (ROS) and reactive nitrogen species (RNS), it is well established that alteration of NADPH oxidase and nitric oxide synthase (NOS) activity leads to the accumulation of these harmful substances which promote chronic inflammation and, as described in the above chapter, cancer development $(106,107)$. Bacteria also play fundamental roles in these processes. Some peroxygenase oral microorganisms are involved in this process producing hydrogen peroxide $\left(\mathrm{H}_{2} \mathrm{O}_{2}\right)$ and include Bifidobacterium adolescentis, Lactobacillus acidophilus, L. fermentum, L. jensenii, L. minutus $(90,108)$, Streptococcus gordonii, S. mitis, S. oligofermentans, S. oralis, and S. sanguinis (109).

Other oncogenic substances produced by oral bacteria are represented by sulfides and nitrosamines. Bacteria including Bacteroides and Firmicutes species are capable to ferment the host excessive protein into sulfides and nitrosamines. These harmful substances are able to induce DNA damage in the oncogene or onco-suppressor genes $(110,111)$.

In addition, oral microorganisms, including Bifidobacterium, Lactobacillus, Lactococcus, Leuconostoc, Pediococcus, Peptostreptococcus stomatis and Streptococcus produce several types of acids (lactic, acetic, butyric, isobutyric, isovaleric, and isocaproic acids), which reduce the environmental $\mathrm{pH}$ (112-114). These acids contribute to the establishment of an ideal tissue microenvironment favorable for cancer cell proliferation and metastatic spread $(115,116)$.

Other studies highlighted the importance of superoxide dismutase (SOD) activity and its expression through the analysis of microbiomes detected in cancer samples and normal mucosa of oral cancer patients (117). The SOD activity is fundamental for inhibiting the detrimental effects of $\mathrm{O}_{2}{ }^{-}$. In particular, it was shown that in tumor samples the presence of $\mathrm{Fe}^{2+}$ reacts with $\mathrm{H}_{2} \mathrm{O}_{2}$ leading to the production of harmful reactive species that promote neoplastic transformation by inducing DNA mutations affecting key genes involved in the regulation of cell cycle (118).

Yost et al reported that in cancer patients, both in tumor or normal sites, microbiome tryptophanase activities are a possible carcinogenetic mechanism. In particular, the higher metabolism of L-tryptophan to secondary metabolites (indole, pyruvate and ammonium) seems to be related to cancer development (117). In this context, the role of aryl hydrocarbon receptor (AHR) is fundamental (119). Similarly, other enzymes, such as glutamate dehydrogenase (GDH), are overexpressed in oral cancer patients and their imbalance may contribute to the alteration of the cellular redox state $(120,121)$.

Finally, as stated above, several oral microorganisms (S. gordonii, S. mitis, S. oralis, S. salivarius, S. sanguinis (122), and Candida yeasts (123) are involved in alcohol metabolizing to acetaldehyde, which has a carcinogenic potential $(68,123)$. All these bacteria constitute a risk for OSCC development due to their acetaldehyde production $(124,125)$.
Integrity alteration of epithelial barrier. In a recent review, Pang et al described the role of dysbiosis in the alteration of epithelial barriers in homeostasis and immune activation, as well as the relationship with carcinogenesis (76). Changes taking place in anatomic structure or in microbial composition and mucus production may lead to an epithelial barrier dysfunction and microenvironment alterations (126). The consequent imbalance between epithelia/microbiota are key factors both in infections and other microbial diseases, including tumor $(127,128)$.

Moreover, as aforementioned, pro-inflammatory conditions sustained by microbial alterations contribute to epithelial barrier alteration. According to Virchow (1881) (129), the inflammatory events are linked to microbiota and cancer. In addition, inflammation may modify the bacteria population, favor microbial translocation and induce the growth of specific bacteria $(126,129,130)$.

Specific microbial metabolites (i.e., ROS and hydroxyl radical) and toxins [such as cytolethal distending toxin (CDT)] generate genomic damages inducing the neoplastic transformation of epithelial cells. Moreover, bacteria activate several signal transduction pathways through virulence genes, e.g., AvrA virulence factor. Another factor stimulated by bacteriocins and bacterial proteins is the transforming growth factor $\beta$ (TGF- $\beta$ ), which induces abnormal cell proliferation $(76,131)$.

Furthermore, TGF- $\beta$ plays a role as an immunomodulating factor inhibiting dendritic cells (DCs); T-receptor cells thus act as tumor-promoter factors (132). Notably, the mechanism of TGF- $\beta$ signaling in promoting tumorigenesis is also associated with the dysregulated inflammation microenvironment actuated by microbiota (76).

Microbiota-induced epigenetic modulation. It has been widely demonstrated that environmental factors, including diet, lifestyle habits, and natural compounds, are responsible for both genetic and epigenetic alterations predisposing the development of several diseases, and have beneficial effects in preventing the development of chronic-degenerative disorders (133-140). In particular, dietary intake and food consumption modulate several cellular and molecular processes acting in a multifactorial manner (141-143). Indeed, the consumption of specific food and nutrients may modulate inflammatory and cell cycle regulatory pathways to maintain the optimal cell homeostasis, preventing the development of diseases $(144,145)$. On the contrary, imbalances of nutrient consumption and/or absorption lead to epigenetic changes associated with certain pathologies, including cancer. The way by which food and nutrient intake is able to influence the onset of certain pathologies remains to be determined. However, findings have shown how foods can change the individual's redox state, the oral and gut microbiota, the DNA methylation status and the alteration of microRNA (miRNAs) expression levels (146-149).

In particular, the two latter epigenetic events are now been recognized as key mechanisms of neoplastic transformation and a plethora of diseases $(12,87,150)$. In this context, recent studies have identified different miRNAs, a class of non-coding RNA of 20-22 nucleotides, associated with the development and progression of different tumors (151-157). In addition, numerous studies have demonstrated the presence of a dual relationship between microbiota and host 
microRNAs (miRNAs) and vice versa (158-160). Liu and co-workers showed that fecal miRNAs produced by epithelial cells and Hopx-positive cells were able to penetrate bacteria (F.nucleatum and $E$ coli) modulating the gene expressions of bacteria and altering the microbiota composition and bacterial cell growth (161). These preliminary observations, obtained in Dicer1-deficient mice, allowed the researchers to conclude that fecal miRNAs exert an important role in the regulation of gut microbiota and microbiome suggesting their possible use as novel therapeutic strategies. Fecal miRNAs are not derived only from intestinal cells. Different studies demonstrated that fecal miRNAs can be derived from foods and can be absorbed by intestinal epithelia modulating the expression levels of host genes $(162,163)$. These miRNAs are mainly planted exosome-derived miRNAs; however, several studies showed that milk-derived miRNAs play key roles (164-166).

All these food-derived miRNAs can presumably interact with oral and gut microbiota $(167,168)$. On this basis, exogenous miRNAs may act as bacterial small RNA to interfere with bacterial gene expression modulating the entire microbiome $(169,170)$. However, further studies are needed to deepen the knowledge on interactions between host-miRNAs and oral/gut microbiota. On the other hand, even the microbiota resident in the oral and intestinal mucosa may modulate the expression of specific miRNAs, thus highlighting a dual relationship between miRNAs and microbiota and their ability to influence each other (171).

One of the mechanisms by which microbiota alters the expression levels of host-epithelial miRNAs is the production of different metabolites leading to significant changes in host-cell metabolism resulting in the alteration of the gene and miRNA expressions (172-174). Pang et al investigated the association among dysbiosis, dysfunction of epithelial barrier and alteration of immune system to evaluate how dysbiosis stimulates carcinogenesis (76).

\section{Oral bacteria with potential carcinogenetic activity}

According to Zhao et al (175), oral cancer samples exhibited more bacterial species compared to healthy individuals. Specifically, Catonella, Dialister, Filifactor, Fusobacterium, Parvimonas, Peptococcus and Peptostreptococcus are the most overexpressed bacteria in OSCC samples with previous periodontitis. Notably, the evaluation of Fusobacterium bacteria was proposed as a diagnostic criterium for OSCC (175). In particular, Fusobacterium nucleatum is responsible, not only for opportunistic infections, but it was recently associated with several kind of cancers (175-179).

In addition, Yost et al (117) performed a preliminary metatranscriptomic study in order to analyze the oral microbiome in oral squamous cell carcinoma patients and establish the connection with the molecular features of this tumor. Authors of that study found increased expression levels of Fusobacteria transcripts in both tumor and peritumoral tissue samples when compared to healthy individuals. Interestingly, they also showed that Fusobacteria virulence factors may be involved in the pathogenesis of oral cancer (117). Outcomes of that study are in agreement with findings of Nagy et al (50) who observed some oral bacteria correlated with keratinizing squa- mous cell carcinomas, including Fusobacterium sp. Moreover, Yang et al (180) correlated the microbiome variations to cancer progression. The Fusobacteria abundance was significantly higher in oral cancer patients showing progression and these data were more evident in stage 4 patients $(7.92 \%)$ compared to healthy controls $(2.98 \%)$ (180).

Lim et al (181) analyzed oral rinse to evaluate the microbiome variations and their correlation oral and head and neck cancers. Those authors identified a panel of bacteria (Capnocytophaga, Corynebacterium, Haemophilus, Oribacterium, Paludibacter, Porphyromonas, and Rothia) to discern oral cavity cancer patients (OCC), oropharyngeal cancer patients (OPC) and healthy subjects (181). On the basis of results obtained, the authors proposed the detection of these bacteria to predict the risk of OCC and OPC, reaching 100 and $90 \%$ sensitivity and specificity, respectively (182). The outcomes of that study are in agreement with previous studies $(49,51,53,182-184)$ that indicated Capnocytophaga gingivalis, Peptostreptococcus sp., Porphyromonas gingivalis, Prevotella sp., and Streptococcus sp. as the oral microorganism mostly associated with OSCCs.

Yost and collaborators demonstrated that among various examined species, Capnocytophaga gingivalis was the more represented in non-tumoral sites. These contrasted results could be due to the different samples examined, as well as to the number of cases enrolled (117). Other bacteria associated with head, neck, and esophageal cancers were streptococci, of which Streptococcus anginosus represents the most important bacterium $(51,185,186)$.

Recently, Yang et al (187) investigated the functional role of microbiota changes related to the genetic alterations observed in OSCC patients. The analysis of saliva samples demonstrated an imbalance in the oral cavity taxa showing a relative abundance of Bacteroidetes and Firmicutes in three different groups of oral cancer clustered according to the mutational status. Moreover, significant variations of microorganism diversity were highlighted through analysis of the three groups of patients. Based on these results, the authors proposed a possible association between mutation in OSCC and alteration of microbiota and microbiome (187). Differences in bacterial composition were also detected between precancerous lesions and cancer samples (53). The results of that study showed that salivary microbiota patterns were importantly modulated in the three analyzed groups. In particular, the genera Bacillus, Enterococcus, Parvimonas, Peptostreptococcus, and Slackia showed a predictive value for discrimination between precancerous and neoplastic lesions (53).

\section{Anti-tumoral effects of probiotics}

In recent years, it was widely demonstrated that the consumption of healthy foods enriched with probiotic acid lactic bacteria has positive effects regarding tumor prevention. Probiotics are able to reduce the mutagenic effects of harmful substances while modulating the expression of proteins involved in cell proliferation, apoptosis, inflammation, or immune system activation (188). Several in vitro experiments performed on cancer cells showed that probiotics possess 
anti-proliferative and pro-apoptotic effects in these tumor models (189). Lee and co-workers demonstrated that the cytoplasmic elements of Bifidobacterium longum, L. acidophilus and $L$. casei exert anti-neoplastic effects in different tumor in vitro models (190). Besides these probiotics, Bacillus polyfermenticus (191), Lactobacillus acidophilus 606 (192), LGG/Bb12 (193), LGG/Bifidobacterium animalis subsp. lactis (194), and Lactobacillus rhamnosus $G G$ (9) possessed anti-neoplastic effects in colorectal cancer cell lines.

Few data are available on the effects of probiotics on oral cancer. In a recent study, HSC-3 OSCC cell lines were used to determine the effects of Lactobacillus rhamnosus $G G$ (LGG) in increasing the antiblastic effects of geniposide, a derivate of Gardenia jasminoides which in preclinical studies showed important anticancer effects $(58,195)$. The results obtained by the authors showed that the combined treatment with geniposide and LGG increased the apoptotic rate of HSC-3 cells. In particular, in a synergistic manner, LGG intensified the antineoplastic action of geniposide, supporting the tentative use of this combined therapy also in clinical practice. In another study, Asoudeh-Fard et al (196) demonstrated that Lactobacillus plantarum was able to inhibit and activate the MAPKs and PTEN pathways, respectively, playing a potential role in the regulation of cancer. Indeed, it is well known that PTEN and MAPKs are associated with the inhibition and the initiation of cancer development, respectively (196). Consequently, a possible use of $L$. plantarum for probiotics cancer therapy was proposed.

In addition, Aghazadeh et al (197) showed that Acetobacter syzygii strain secretions possess anticancer activity promoting the apoptosis induction in oral cancer cells. Interestingly, Acetobacter syzygii products were not involved in the alteration of homeostasis of the epithelial cell line (197). These findings seem to show the crucial role represented by the microorganism in controlling cancer development in oral tissues and encourage further investigations on the effect of probiotics on OSCC development.

\section{Conclusions}

This review widely discussed how the dysregulation of oral microbiota and oral mucosa homeostasis may represent modifiable risk factors associated with the development of OSCC. In addition, it was shown that certain bacterial strains may play a protective role against oral neoplastic transformation suggesting the possible use of probiotics administration as novel preventive and therapeutic strategies. In this scenario, several species have been strongly correlated with oral carcinoma, such as Capnocytophaga gingivalis, Fusobacterium sp., Streptococcus sp., Peptostreptococcus sp., Porphyromonas gingivalis and Prevotella sp., due to the fact that these bacteria may promote inflammation, cell proliferation and the production of some oncogenic substances (90). Recent findings have shown that the evaluation of oral microbiota and microbiome may provide important information on oral cancer oncogenesis, outcome prediction and therapeutic response (including immunotherapy) $(198,199)$. In addition, thanks to the new high-throughput molecular technologies it was possible to define the precise composition and gene expression (micro- biome) of oral bacteria in OSCC patients and normal controls identifying specific strains associated with an increased risk of OSCC development $(1,200)$. Therefore, the analysis of circulating biomarkers (miRNAs, circulating DNA, specific proteins) represents a good approach for the assessment of oral cancer risk (201-203).

In this respect, the use of probiotics that in appropriate amounts give a health benefit to the host, including anti-tumoral effects, could be useful to promote cancer therapies representing a new step of the evolution of anticancer pharmacological treatments $(190,204)$. Although in vitro and in vivo experiments demonstrated the beneficial effects probiotics (7-9), few data are available about the efficacy of probiotics in oral cancer. It is reasonable to hypothesize that the beneficial effects exert by probiotics in intestinal and colorectal cancer is similar to those acted in the oral mucosa. Starting from this assumption, future studies are required to explore the involvement of oral microbiota and its relationship with oral cancer.

\section{Acknowledgements}

Not applicable.

\section{Funding}

No funding was received.

\section{Availability of data and materials}

The datasets used and/or analyzed during the current study are available from the corresponding author on reasonable request.

\section{Authors' contributions}

GRMLR, DN and MS conceived the study. GG, EP provided the information about microbiota and oral cancer. GRMLR, GG and EP organized the Tables. GG and DN were involved in the preparation of the figure. GRMLR, EP, ER and MS were involved in the preparation of the original draft of the manuscript, while DN, ER and MS reviewed and edited the article. All authors have read and approved the final version of the manuscript.

\section{Ethics approval and consent to participate}

Not applicable.

\section{Patient consent for publication}

Not applicable.

\section{Competing interests}

The authors declare that they have no competing interests.

\section{References}

1. Ferlay J, Colombet M, Soerjomataram I, Mathers C, Parkin DM, Piñeros M, Znaor A and Bray F: Estimating the global cancer incidence and mortality in 2018: GLOBOCAN sources and methods. Int J Cancer 144: 1941-1953, 2019. 
2. Fenga C, Gangemi S, Di Salvatore V, Falzone L and Libra M Immunological effects of occupational exposure to lead (Review). Mol Med Rep 15: 3355-3360, 2017 (Review).

3. Rapisarda V, Ledda C, Matera S, Fago L, Arrabito G, Falzone L, Marconi A, Libra M and Loreto C: Absence of $t(14 ; 18)$ chromosome translocation in agricultural workers after short-term exposure to pesticides. Mol Med Rep 15: 3379-3382, 2017.

4. Rapisarda V, Salemi R, Marconi A, Loreto C, Graziano AC, Cardile V, Basile MS, Candido S, Falzone L, Spandidos DA, et al: Fluoro-edenite induces fibulin-3 overexpression in non-malignant human mesothelial cells. Oncol Lett 12: 3363-3367, 2016.

5. Falzone L, Marconi A, Loreto C, Franco S, Spandidos DA and Libra M: Occupational exposure to carcinogens: Benzene, pesticides and fibers (Review). Mol Med Rep 14: 4467-4474, 2016 (Review).

6. Malfa GA, Tomasello B, Sinatra F, Villaggio G, Amenta F, Avola R and Renis M: 'Reactive' response evaluation of primary human astrocytes after methylmercury exposure. J Neurosci Res 92: 95-103, 2014.

7. Vivarelli S, Salemi R, Candido S, Falzone L, Santagati M, Stefani S, Torino F, Banna GL, Tonini G and Libra M: Gut Microbiota and Cancer: From Pathogenesis to Therapy. Cancers (Basel) 11: E38, 2019.

8. Banna GL, Torino F, Marletta F, Santagati M, Salemi R, Cannarozzo E, Falzone L, Ferraù F and Libra M: Lactobacillus rhamnosus $G G$ : An overview to explore the rationale of its use in cancer. Front Pharmacol 8: 603, 2017.

9. Vivarelli S, Falzone L, Basile MS, Nicolosi D, Genovese C, Libra $\mathrm{M}$ and Salmeri M: Benefits of using probiotics as adjuvants in anticancer therapy. World Ac Sci J 1: 125-135, 2019 (Review).

10. Garozzo A, Falzone L, Rapisarda V, Marconi A, Cinà D, Fenga C, Spandidos DA and Libra M: The risk of HCV infection among health-care workers and its association with extrahepatic manifestations (Review). Mol Med Rep 15: 3336-3339, 2017 (Review).

11. Ng JH, Iyer NG, Tan MH and Edgren G: Changing epidemiology of oral squamous cell carcinoma of the tongue: A global study. Head Neck 39: 297-304, 2017.

12. Falzone L, Lupo G, La Rosa GRM, Crimi S, Anfuso CD, Salemi R, Rapisarda E, Libra M and Candido S: Identification of novel micrornas and their diagnostic and prognostic significance in oral cancer. Cancers (Basel) 11: E610, 2019.

13. Graham S, Dayal H, Rohrer T, Swanson M, Sultz H, Shedd D and Fischman S: Dentition, diet, tobacco, and alcohol in the epidemiology of oral cancer. J Natl Cancer Inst 59: 1611-1618, 1977.

14. Marshall JR, Graham S, Haughey BP, Shedd D, O'Shea R, Brasure J, Wilkinson GS and West D: Smoking, alcohol, dentition and diet in the epidemiology of oral cancer. Eur J Cancer B Oral Oncol 28B: 9-15, 1992.

15. Aggarwal BB, Vijayalekshmi RV and Sung B: Targeting inflammatory pathways for prevention and therapy of cancer: Short-term friend, long-term foe. Clin Cancer Res 15: 425-430, 2009.

16. Read SA and Douglas MW: Virus induced inflammation and cancer development. Cancer Lett 345: 174-181, 2014.

17. Wang F, Meng W, Wang B and Qiao L: Helicobacter pyloriinduced gastric inflammation and gastric cancer. Cancer Lett 345: 196-202, 2014.

18. Turnbaugh PJ, Ley RE, Hamady M, Fraser-Liggett CM, Knight R and Gordon JI: The human microbiome project. Nature 449: 804-810, 2007.

19. Dewhirst FE, Chen T, Izard J, Paster BJ, Tanner AC, Yu WH, Lakshmanan A and Wade WG: The human oral microbiome. J Bacteriol 192: 5002-5017, 2010.

20. Kolenbrander PE, Andersen RN, Blehert DS, Egland PG, Foster JS and Palmer RJJ Jr: Communication among oral bacteria. Microbiol Mol Biol Rev 66: 486-505, 2002.

21. Al-Maweri SA, Warnakulasuriya S and Samran A: Khat (Catha edulis) and its oral health effects: An updated review. J Investig Clin Dent 9: 2018. https://doi.org/10.1111/jicd.12288.

22. Leonardi R, Loreto C, Barbato E, Polimeni A, Caltabiano R and Lo Muzio L: A histochemical survey of the human temporomandibular joint disc of patients with internal derangement without reduction. J Craniofac Surg 18: 1429-1433, 2007.

23. Petralia MC, Mazzon E, Fagone P, Falzone L, Bramanti P, Nicoletti F and Basile MS: Retrospective follow-up analysis of the transcriptomic patterns of cytokines, cytokine receptors and chemokines at preconception and during pregnancy, in women with post-partum depression. Exp Ther Med 18: 2055-2062, 2019

24. Vesty A, Gear K, Biswas K, Radcliff FJ, Taylor MW and Douglas RG: Microbial and inflammatory-based salivary biomarkers of head and neck squamous cell carcinoma. Clin Exp Dent Res 4: 255-262, 2018.
25. Meurman JH: Oral microbiota and cancer. J Oral Microbiol 2 : 2, 2010.

26. Pennisi M, Malaguarnera G, Bartolo GD, Lanza G, Bella R, Chisari EM, Cauli O, Vicari E and Malaguarnera M: Decrease in Serum Vitamin D Level of Older Patients with Fatigue. Nutrients 11: E2531, 2019.

27. Pennisi M, Di Bartolo G, Malaguarnera G, Bella R, Lanza G, Malaguarnera $M$ and Vitamin D: Vitamin D serum levels in patients with statin-induced musculoskeletal pain. Dis Markers 2019: 3549402, 2019.

28. Human Microbiome Project Consortium: A framework for human microbiome research. Nature 486: 215-221, 2012.

29. Marasco G, Di Biase AR, Schiumerini R, Eusebi LH, Iughetti L, Ravaioli F, Scaioli E, Colecchia A and Festi D: Gut microbiota and celiac disease. Dig Dis Sci 61: 1461-1472, 2016.

30. Quigley EMM: Microbiota-brain-gut axis and neurodegenerative diseases. Curr Neurol Neurosci Rep 17: 94, 2017.

31. Yang T and Zubcevic J: Gut-brain axis in regulation of blood pressure. Front Physiol 8: 845, 2017.

32. Vinciguerra L, Lanza G, Puglisi V, Pennisi M, Cantone M, Bramanti A, Pennisi G and Bella R: Transcranial Doppler ultrasound in vascular cognitive impairment-no dementia. PLoS One 14: e0216162, 2019.

33. Puglisi V, Bramanti A, Lanza G, Cantone M, Vinciguerra L, Pennisi M, Bonanno L, Pennisi G and Bella R: Impaired cerebral haemodynamics in vascular depression: insights from transcranial doppler ultrasonography. Front Psychiatry 9: 316, 2018.

34. Lanza G, Cantone M, Musso S, Borgione E, Scuderi C and Ferri R: Early-onset subcortical ischemic vascular dementia in an adult with mtDNA mutation $3316 \mathrm{G}>\mathrm{A}$. J Neurol 265: 968-969, 2018.

35. Bordet R, Ihl R, Korczyn AD, Lanza G, Jansa J, Hoerr R and Guekht A: Towards the concept of disease-modifier in poststroke or vascular cognitive impairment: A consensus report. BMC Med 15: 107, 2017.

36. Lanza G, Bramanti P, Cantone M, Pennisi M, Pennisi G and Bella R: Vascular cognitive impairment through the looking glass of transcranial magnetic stimulation. Behav Neurol 2017: 1421326, 2017.

37. Bella R, Cantone M, Lanza G, Ferri R, Vinciguerra L, Puglisi V, Pennisi M, Ricceri R, Di Lazzaro V and Pennisi G: Cholinergic circuitry functioning in patients with vascular cognitive impairment - no dementia. Brain Stimul 9: 225-233, 2016.

38. Pennisi M, Lanza G, Cantone M, Ricceri R, Spampinato C, Pennisi G, Di Lazzaro V and Bella R: Correlation between motor cortex excitability changes and cognitive impairment in vascular depression: Pathophysiological insights from a longitudinal TMS study. Neural Plast 2016: 8154969, 2016.

39. Pennisi G, Bella R and Lanza G: Motor cortex plasticity in subcortical ischemic vascular dementia: What can TMS say? Clin Neurophysiol 126: 851-852, 2015.

40. Lanza G, Papotto M, Pennisi G, Bella R and Ferri R: Epileptic seizure as a precipitating factor of vascular progressive supranuclear palsy: A case report. J Stroke Cerebrovasc Dis 23: e379-e381, 2014

41. Concerto C, Lanza G, Cantone M, Pennisi M, Giordano D, Spampinato C, Ricceri R, Pennisi G, Aguglia E and Bella R: Different patterns of cortical excitability in major depression and vascular depression: A transcranial magnetic stimulation study. BMC Psychiatry 13: 300, 2013

42. Bella R, Ferri R, Lanza G, Cantone M, Pennisi M, Puglisi V, Vinciguerra L, Spampinato C, Mazza T, Malaguarnera G, et al: TMS follow-up study in patients with vascular cognitive impairment-no dementia. Neurosci Lett 534: 155-159, 2013.

43. Bella R, Ferri R, Cantone M,Pennisi M,Lanza G, Malaguarnera G, Spampinato C, Giordano D, Raggi A and Pennisi G: Motor cortex excitability in vascular depression. Int J Psychophysiol 82: 248-253, 2011.

44. Bella R,Ferri R,Pennisi M,Cantone M,Lanza G, Malaguarnera G, Spampinato C, Giordano D, Alagona G and Pennisi G: Enhanced motor cortex facilitation in patients with vascular cognitive impairment-no dementia. Neurosci Lett 503: 171-175, 2011.

45. Pennisi G,Ferri R, Cantone M,Lanza G,Pennisi M, Vinciguerra L, Malaguarnera $\mathrm{G}$ and Bella R: A review of transcranial magnetic stimulation in vascular dementia. Dement Geriatr Cogn Disord 31: 71-80, 2011.

46. Bella R, Pennisi G, Cantone M, Palermo F, Pennisi M, Lanza G, Zappia M and Paolucci S: Clinical presentation and outcome of geriatric depression in subcortical ischemic vascular disease. Gerontology 56: 298-302, 2010. 
47. Atanasova KR and Yilmaz O: Looking in the Porphyromonas gingivalis cabinet of curiosities: The microbium, the host and cancer association. Mol Oral Microbiol 29: 55-66, 2014.

48. Yilmaz O: The chronicles of Porphyromonas gingivalis: The microbium, the human oral epithelium and their interplay. Microbiology 154: 2897-2903, 2008.

49. Katz J, Onate MD, Pauley KM, Bhattacharyya I and Cha S: Presence of Porphyromonas gingivalis in gingival squamous cell carcinoma. Int J Oral Sci 3: 209-215, 2011.

50. Nagy KN, Sonkodi I, Szöke I, Nagy E and Newman HN: The microflora associated with human oral carcinomas. Oral Oncol 34: 304-308, 1998.

51. Mager DL, Haffajee AD, Devlin PM, Norris CM, Posner MR and Goodson JM: The salivary microbiota as a diagnostic indicator of oral cancer: A descriptive, non-randomized study of cancerfree and oral squamous cell carcinoma subjects. J Transl Med 3: $27,2005$.

52. Hu X, Zhang Q, Hua $\mathrm{H}$ and Chen F: Changes in the salivary microbiota of oral leukoplakia and oral cancer. Oral Oncol 56 : e6-e8, 2016.

53. Lee WH, Chen HM, Yang SF, Liang C, Peng CY, Lin FM, Tsai LL, Wu BC, Hsin CH, Chuang CY, et al: Bacterial alterations in salivary microbiota and their association in oral cancer. Sci Rep 7: 16540, 2017.

54. Pepe MS, Etzioni R, Feng Z, Potter JD, Thompson ML, Thornquist M, Winget $\mathrm{M}$ and Yasui Y: Phases of biomarker development for early detection of cancer. J Natl Cancer Inst 93: 1054-1061, 2001.

55. Lucs A, Saltman B, Chung CH, Steinberg BM and Schwartz DL: Opportunities and challenges facing biomarker development for personalized head and neck cancer treatment. Head Neck 35 : 294-306, 2013.

56. Meurman JH and Stamatova I: Probiotics: Contributions to oral health. Oral Dis 13: 443-451, 2007.

57. Stamatova I and Meurman JH: Probiotics: Health benefits in the mouth. Am J Dent 22: 329-338, 2009.

58. Cheng Z, Xu H, Wang X and Liu Z: Lactobacillus raises in vitro anticancer effect of geniposide in HSC-3 human oral squamous cell carcinoma cells. Exp Ther Med 14: 4586-4594, 2017.

59. Chang JS, Lo HI, Wong TY, Huang CC, Lee WT, Tsai ST, Chen KC, Yen CJ, Wu YH, Hsueh WT, et al: Investigating the association between oral hygiene and head and neck cancer. Oral Oncol 49: 1010-1017, 2013.

60. Rosenquist K, Wennerberg J, Schildt EB, Bladström A, Göran Hansson B and Andersson G: Oral status, oral infections and some lifestyle factors as risk factors for oral and oropharyngeal squamous cell carcinoma. A population-based case-control study in southern Sweden. Acta Otolaryngol 125: 1327-1336, 2005

61. Divaris K, Olshan AF, Smith J, Bell ME, Weissler MC, Funkhouser WK and Bradshaw PT: Oral health and risk for head and neck squamous cell carcinoma: The Carolina Head and Neck Cancer Study. Cancer Causes Control 21: 567-575, 2010.

62. Garrote LF, Herrero R, Reyes RM, Vaccarella S, Anta JL, Ferbeye L, Muñoz N and Franceschi S: Risk factors for cancer of the oral cavity and oro-pharynx in Cuba. Br J Cancer 85: 46-54, 2001.

63. Michaud DS, Liu Y, Meyer M, Giovannucci E and Joshipura K: Periodontal disease, tooth loss, and cancer risk in male health professionals: A prospective cohort study. Lancet Oncol 9: 550-558, 2008.

64. Tezal M, Sullivan MA, Reid ME, Marshall JR, Hyland A, Loree T, Lillis C, Hauck L, Wactawski-Wende $\mathrm{J}$ and Scannapieco FA: Chronic periodontitis and the risk of tongue cancer. Arch Otolaryngol Head Neck Surg 133: 450-454, 2007.

65. Tezal M, Sullivan MA, Hyland A, Marshall JR, Stoler D, Reid ME, Loree TR, Rigual NR, Merzianu M, Hauck L, et al: Chronic periodontitis and the incidence of head and neck squamous cell carcinoma. Cancer Epidemiol Biomarkers Prev 18: 2406-2412, 2009.

66. Holmes L Jr, desVignes-Kendrick M, Slomka J, Mahabir S, Beeravolu S and Emani SR: Is dental care utilization associated with oral cavity cancer in a large sample of community-based United States residents? Community Dent Oral Epidemiol 37: 134-142, 2009.

67. Börnigen D, Ren B, Pickard R, Li J, Ozer E, Hartmann EM, Xiao W, Tickle T, Rider J, Gevers D, et al: Alterations in oral bacterial communities are associated with risk factors for oral and oropharyngeal cancer. Sci Rep 7: 17686, 2017.
68. Vogelmann R and Amieva MR: The role of bacterial pathogens in cancer. Curr Opin Microbiol 10: 76-81, 2007.

69. Lim Y, Totsika M, Morrison M and Punyadeera C: Oral microbiome: A new biomarker reservoir for oral and oropharyngeal cancers. Theranostics 7: 4313-4321, 2017.

70. Cali F, Cantone M, Cosentino FII, Lanza G, Ruggeri G, Chiavetta V, Salluzzo R, Ragalmuto A, Vinci M and Ferri R: Interpreting genetic variants: hints from a family cluster of Parkinson's disease. J Parkinsons Dis 9: 203-206, 2019.

71. Pennisi M, Lanza G, Cantone M, Schepis C, Ferri R, Barone R and Bella R: Unusual neurological presentation of nevoid basal cell carcinoma syndrome (Gorlin-Goltz Syndrome). J Clin Neurol 13: 439-441, 2017.

72. Zhang Y, Wang X, Li H, Ni C, Du Z and Yan F: Human oral microbiota and its modulation for oral health. Biomed Pharmacother 99: 883-893, 2018.

73. Guarneri C, Bevelacqua V, Polesel J, Falzone L, Cannavò PS, Spandidos DA, Malaponte G and Libra M: NF- $\kappa$ B inhibition is associated with OPN/MMP 9 downregulation in cutaneous melanoma. Oncol Rep 37: 737-746, 2017.

74. Leonardi GC, Falzone L, Salemi R, Zanghì A, Spandidos DA, Mccubrey JA, Candido S and Libra M: Cutaneous melanoma: From pathogenesis to therapy (Review). Int J Oncol 52: 1071-1080, 2018. (Review).

75. Dolcet X, Llobet D, Pallares J and Matias-Guiu X: NF- $\kappa B$ in development and progression of human cancer. Virchows Arch 446: 475-482, 2005.

76. Pang X, Tang YJ, Ren XH, Chen QM, Tang YL and Liang XH: Microbiota, epithelium, inflammation, and TGF- $\beta$ signaling: An intricate interaction in oncogenesis. Front Microbiol 9: 1353, 2018.

77. Couturier-Maillard A, Secher T, Rehman A, Normand S, De Arcangelis A, Haesler R, Huot L, Grandjean T, Bressenot A, Delanoye-Crespin A, et al: NOD2-mediated dysbiosis predisposes mice to transmissible colitis and colorectal cancer. J Clin Invest 123: 700-711, 2013.

78. Hu B, Elinav E, Huber S, Strowig T, Hao L, Hafemann A, Jin C, Wunderlich C, Wunderlich T, Eisenbarth SC, et al: Microbiota-induced activation of epithelial IL- 6 signaling links inflammasome-driven inflammation with transmissible cancer. Proc Natl Acad Sci USA 110: 9862-9867, 2013.

79. Francescone R, Hou V and Grivennikov SI: Microbiome, inflammation, and cancer. Cancer J 20: 181-189, 2014.

80. Ojesina AI, Lichtenstein L, Freeman SS, Pedamallu CS, Imaz-Rosshandler I, Pugh TJ, Cherniack AD, Ambrogio L, Cibulskis K, Bertelsen B, et al: Landscape of genomic alterations in cervical carcinomas. Nature 506: 371-375, 2014.

81. Allen J and Sears CL: Impact of the gut microbiome on the genome and epigenome of colon epithelial cells: Contributions to colorectal cancer development. Genome Med 11: 11, 2019.

82. Multhoff G, Molls M and Radons J: Chronic inflammation in cancer development. Front Immunol 2: 98, 2012.

83. Szkaradkiewicz AK: Karpiński TM: Microbiology of chronic periodontitis. J Biol Earth Sci 3: M14-M20, 2013.

84. Leonardi R, Talic NF and Loreto C: MMP-13 (collagenase 3) immunolocalisation during initial orthodontic tooth movement in rats. Acta Histochem 109: 215-220, 2007.

85. Salemi R, Falzone L, Madonna G, Polesel J, Cinà D, Mallardo D, Ascierto PA, Libra M and Candido S: MMP-9 as a candidate marker of response to BRAF inhibitors in melanoma patients with BRAFV600E mutation detected in circulating-free DNA. Front Pharmacol 9: 856, 2018.

86. Silva EM, Mariano VS, Pastrez PRA, Pinto MC, Castro AG, Syrjanen KJ and Longatto-Filho A: High systemic IL-6 is associated with worse prognosis in patients with non-small cell lung cancer. PLoS One 12: e0181125, 2017.

87.Falzone L, Salemi R, Travali S, Scalisi A, McCubrey JA Candido $\mathrm{S}$ and Libra M: MMP-9 overexpression is associated with intragenic hypermethylation of MMP9 gene in melanoma. Aging (Albany NY) 8: 933-944, 2016.

88. Katz J, Wallet S and Cha S: Periodontal disease and the oral-systemic connection: 'is it all the RAGE?'. Quintessence Int 41: 229-237, 2010.

89.Zhang G and Ghosh S: Molecular mechanisms of NF-kappaB activation induced by bacterial lipopolysaccharide through Toll-like receptors. J Endotoxin Res 6: 453-457, 2000.

90. Karpiński TM: Role of oral microbiota in cancer development. Microorganisms 7: E20, 2019.

91. Hou LT, Liu CM, Liu BY, Lin SJ, Liao CS and Rossomando EF: Interleukin-lbeta, clinical parameters and matched cellularhistopathologic changes of biopsied gingival tissue from periodontitis patients. J Periodontal Res 38: 247-254, 2003. 
92. Konopka $€$ and Brzezinska Błaszczyk E: Cytokines in gingival crevicular fluidas potential diagnostic and prognostic markers of periodontitis. Dent Med Probl 47: 206-213, 2010.

93. Carmi Y, Dotan S, Rider P, Kaplanov I, White MR, Baron R, Abutbul S, Huszar M, Dinarello CA, Apte RN, et al: The role of IL-1 $\beta$ in the early tumor cell-induced angiogenic response. J Immunol 190: 3500-3509, 2013.

94. Jin L, Yuan RQ, Fuchs A, Yao Y, Joseph A, Schwall R, Schnitt SJ, Guida A, Hastings HM, Andres J, et al: Expression of interleukin-1beta in human breast carcinoma. Cancer 80: 421-434, 1997.

95. Voronov E, Shouval DS, Krelin Y, Cagnano E, Benharroch D, Iwakura Y, Dinarello CA and Apte RN: IL-1 is required for tumor invasiveness and angiogenesis. Proc Natl Acad Sci USA 100: 2645-2650, 2003

96.Pannone G, Santoro A, Feola A, Bufo P, Papagerakis P, Lo Muzio L, Staibano S, Ionna F, Longo F, Franco R, et al: The role of E-cadherin down-regulation in oral cancer: $\mathrm{CDH} 1$ gene expression and epigenetic blockage. Curr Cancer Drug Targets 14: $115-127,2014$

97. Wong SHM, Fang CM, Chuah LH, Leong CO and Ngai SC: E-cadherin: Its dysregulation in carcinogenesis and clinical implications. Crit Rev Oncol Hematol 121: 11-22, 2018

98. Kossakowska AE, Edwards DR, Prusinkiewicz C Zhang MC, Guo D, Urbanski SJ, Grogan T, Marquez LA and Janowska-Wieczorek A: Interleukin-6 regulation of matrix metalloproteinase (MMP-2 and MMP-9) and tissue inhibitor of metalloproteinase (TIMP-1) expression in malignant nonHodgkin's lymphomas. Blood 94: 2080-2089, 1999

99. Natali P, Nicotra MR, Cavaliere R, Bigotti A, Romano G, Temponi $\mathrm{M}$ and Ferrone S: Differential expression of intercellular adhesion molecule 1 in primary and metastatic melanoma lesions. Cancer Res 50: 1271-1278, 1990.

100. Haura EB, Turkson J and Jove R: Mechanisms of disease: Insights into the emerging role of signal transducers and activators of transcription in cancer. Nat Clin Pract Oncol 2: 315-324, 2005.

101. Szlosarek P, Charles KA and Balkwill FR: Tumour necrosis factor-alpha as a tumour promoter. Eur J Cancer 42: 745-750, 2006

102. Rivas MA, Carnevale RP, Proietti CJ, Rosemblit C, Beguelin W, Salatino M, Charreau EH, Frahm I, Sapia S, Brouckaert P, et al: TNF alpha acting on TNFR1 promotes breast cancer growth via p42/P44 MAPK, JNK, Akt and NF-kappa B-dependent pathways. Exp Cell Res 314: 509-529, 2008.

103. Karin M: NF-kappaB as a critical link between inflammation and cancer. Cold Spring Harb Perspect Biol 1: a000141, 2009

104. Hoesel B and Schmid JA: The complexity of NF- $\kappa$ B signaling in inflammation and cancer. Mol Cancer 12: 86, 2013.

105. Agassandian $M$ and Shurin GV: Bacterial Infections and Cancar Development. In: Shurin MR, Thanavala Y, Ismail N, editors Infection and Cancaer: Bi-Directorial Interactions; 1 ed. Springer International Publishing; 2015: 408, 2015.

106. Hussain SP, Hofseth LJ and Harris CC: Radical causes of cancer Nat Rev Cancer 3: 276-285, 2003.

107.Piao JY, Lee HG, Kim SJ, Kim DH, Han HJ, Ngo HK, Park SA, Woo JH, Lee JS, Na HK, et al: Helicobacter pylori activates IL-6-STAT3 signaling in human gastric cancer cells: Potential roles for reactive oxygen species. Helicobacter 21: 405-416, 2016

108. Brauncajs M and Sakowska D: Krzemiński Z: Production of hydrogen peroxide by lactobacilli colonising the human oral cavity. Med Dosw Mikrobiol 53: 331-336, 2001.

109. Abranches J, Zeng L, Kajfasz JK, Palmer SR, Chakraborty B, Wen ZT, Richards VP, Brady LJ and Lemos JA: Biology of oral streptococci. Microbiol Spectr 6: 6, 2018.

110. Carbonero F, Benefiel AC, Alizadeh-Ghamsari AH and Gaskins HR: Microbial pathways in colonic sulfur metabolism and links with health and disease. Front Physiol 3: 448, 2012.

111. Bhatt AP, Redinbo MR and Bultman SJ: The role of the microbiome in cancer development and therapy. CA Cancer J Clin 67: 326-344, 2017

112. Karpiński TM and Szkaradkiewicz AK: Karpiński TM, Szkaradkiewicz AK: Characteristic of bacteriocines and their application. Pol J Microbiol 62: 223-235, 2013.

113. Senneby A, Davies JR, Svensäter G and Neilands J: Acid tolerance properties of dental biofilms in vivo. BMC Microbio 17: $165,2017$.

114. Downes J and Wade WG: Peptostreptococcus stomatis sp. nov., isolated from the human oral cavity. Int J Syst Evol Microbiol 56: 751-754, 2006.

115. Lunt SJ, Chaudary N and Hill RP: The tumor microenvironment and metastatic disease. Clin Exp Metastasis 26: 19-34, 2009.
116. Mazzio EA, Smith B and Soliman KF: Evaluation of endogenous acidic metabolic products associated with carbohydrate metabolism in tumor cells. Cell Biol Toxicol 26: 177-188, 2010.

117. Yost S, Stashenko P, Choi Y, Kukuruzinska M, Genco CA, Salama A, Weinberg EO, Kramer CD and Frias-Lopez J: Increased virulence of the oral microbiome in oral squamous cell carcinoma revealed by metatranscriptome analyses. Int J Oral Sci 10: 32, 2018

118. Franco R, Schoneveld O, Georgakilas AG and Panayiotidis MI Oxidative stress, DNA methylation and carcinogenesis. Cancer Lett 266: 6-11,2008.

119. Murray IA, Patterson AD and Perdew GH: Aryl hydrocarbon receptor ligands in cancer: Friend and foe. Nat Rev Cancer 14 801-814, 2014

120. Jin L, Li D, Alesi GN, Fan J, Kang HB, Lu Z, Boggon TJ, Jin P, Yi H, Wright ER, et al: Glutamate dehydrogenase 1 signals through antioxidant glutathione peroxidase 1 to regulate redox homeostasis and tumor growth. Cancer Cell 27: 257-270, 2015.

121. Liu G, Zhu J, Yu M, Cai C, Zhou Y, Yu M, Fu Z, Gong Y, Yang B, Li Y, et al: Glutamate dehydrogenase is a novel prognostic marker and predicts metastases in colorectal cancer patients. J Transl Med 13: 144, 2015.

122. Pavlova SI, Jin L, Gasparovich SR and Tao L: Multiple alcohol dehydrogenases but no functional acetaldehyde dehydrogenase causing excessive acetaldehyde production from ethanol by oral streptococci. Microbiology 159 (159Pt 7): 1437-1446, 2013.

123. Marttila E, Bowyer P, Sanglard D, Uittamo J, Kaihovaara P, Salaspuro M, Richardson M and Rautemaa R: Fermentative 2-carbon metabolism produces carcinogenic levels of acetaldehyde in Candida albicans. Mol Oral Microbiol 28: 281-291, 2013.

124. Salaspuro M: Microbial metabolism of ethanol and acetaldehyde and clinical consequences. Addict Biol 2: 35-46, 1997.

125. Meurman JH and Uittamo J: Oral micro-organisms in the etiology of cancer. Acta Odontol Scand 66: 321-326, 2008.

126. Schwabe RF and Jobin C: The microbiome and cancer. Nat Rev Cancer 13: 800-812, 2013.

127. Sellers RS and Morton D: The colon: From banal to brilliant. Toxicol Pathol 42: 67-81, 2014

128. Taur Y and Pamer EG: Microbiome mediation of infections in the cancer setting. Genome Med 8: 40, 2016.

129. Elinav E, Nowarski R, Thaiss CA, Hu B, Jin C and Flavell RA: Inflammation-induced cancer: Crosstalk between tumours, immune cells and microorganisms. Nat Rev Cancer 13: 759-771, 2013.

130. Arthur JC, Perez-Chanona E, Mühlbauer M, Tomkovich S, Uronis JM, Fan TJ, Campbell BJ, Abujamel T, Dogan B, Rogers AB, et al: Intestinal inflammation targets cancerinducing activity of the microbiota. Science 338: 120-123, 2012.

131. White RA, Malkoski SP and Wang XJ: TGF $\beta$ signaling in head and neck squamous cell carcinoma. Oncogene 29: 5437-5446, 2010.

132. Yang L: TGFbeta and cancer metastasis: An inflammation link. Cancer Metastasis Rev 29: 263-271, 2010.

133.Lanza G, Centonze SS, Destro G, Vella V, Bellomo M, Pennisi M, Bella R and Ciavardelli D: Shiatsu as an adjuvant therapy for depression in patients with Alzheimer's disease: A pilot study. Complement Ther Med 38: 74-78, 2018.

134. Lanza G, Bella R, Cantone M, Pennisi G, Ferri R and Pennisi M: Cognitive impairment and celiac disease: Is transcranial magnetic stimulation a trait d'union between gut and brain? Int J Mol Sci 19: E2243, 2018.

135.Pennisi M, Bramanti A, Cantone M, Pennisi G, Bella R and Lanza G: Neurophysiology of the 'Celiac Brain': Disentangling Gut-Brain Connections. Front Neurosci 11: 498, 2017.

136. Bella R, Lanza G, Cantone M, Giuffrida S, Puglisi V, Vinciguerra L, Pennisi M, Ricceri R, D'Agate CC, Malaguarnera G, et al: Effect of a gluten-free diet on cortical excitability in adults with celiac disease. PLoS One 10 e0129218, 2015

137.Pennisi G, Lanza G, Giuffrida S, Vinciguerra L, Puglisi V, Cantone M, Pennisi M, D'Agate CC, Naso P, Aprile G, et al: Excitability of the motor cortex in de novo patients with celiac disease. PLoS One 9: e102790, 2014.

138. Pennisi M, Lanza G, Cantone M, Ricceri R, Ferri R, D'Agate CC, Pennisi G, Di Lazzaro V and Bella R: Cortical involvement in celiac disease before and after long-term gluten-free diet: A transcranial magnetic stimulation study. PLoS One 12: e0177560, 2017 
139.Tiffon C: The impact of nutrition and environmental epigenetics on human health and disease. Int J Mol Sci 19: E3425, 2018.

140. Acquaviva R, Sorrenti V, Santangelo R, Cardile V, Tomasello B, Malfa G, Vanella L, Amodeo A, Genovese C, Mastrojeni S, et al: Effects of an extract of Celtis aetnensis (Tornab.) Strobl twigs on human colon cancer cell cultures. Oncol Rep 36: 2298-2304, 2016.

141. Malfa GA, Tomasello B, Acquaviva R, Genovese C, La Mantia A, Cammarata FP, Ragusa M, Renis M and Di Giacomo C: Betula etnensis Raf. (Betulaceae) extract induced HO-1 expression and ferroptosis cell death in human colon cancer cells. Int J Mol Sci 20: E2723, 2019.

142. Soldati L, Di Renzo L, Jirillo E, Ascierto PA, Marincola FM and De Lorenzo A: The influence of diet on anti-cancer immune responsiveness. J Transl Med 16: 75, 2018.

143. Farhud D, Zarif Yeganeh M and Zarif Yeganeh M: Nutrigenomics and nutrigenetics. Iran J Public Health 39: 1-14, 2010.

144. Martucci M, Ostan R, Biondi F, Bellavista E, Fabbri C, Bertarelli C, Salvioli S, Capri M, Franceschi C and Santoro A: Mediterranean diet and inflammaging within the hormesis paradigm. Nutr Rev 75: 442-455, 2017

145. Minihane AM, Vinoy S, Russell WR, Baka A, Roche HM, Tuohy KM, Teeling JL, Blaak EE, Fenech M, Vauzour D, et al Low-grade inflammation, diet composition and health: Current research evidence and its translation. Br J Nutr 114: 999-1012, 2015

146. Murtaza N, Burke LM, Vlahovich N, Charlesson B, O'Neill HM, Ross ML, Campbell KL, Krause L and Morrison M: Analysis of the effects of dietary pattern on the oral microbiome of elite endurance athletes. Nutrients 11: E614, 2019.

147. Kadayifci FZ, Zheng S and Pan YX: Molecular mechanisms underlying the link between diet and DNA methylation. Int J Mol Sci 19: E4055, 2018

148. Guillemin GJ, Essa MM, Song BJ and Manivasagam T: Dietary supplements/antioxidants: impact on redox status in brain diseases. Oxid Med Cell Longev 2017: 5048432, 2017.

149. Quintanilha BJ, Reis BZ, Duarte GBS, Cozzolino SMF and Rogero MM: Nutrimiromics: Role of microRNAs and nutrition in modulating inflammation and chronic diseases. Nutrients 9: E1168, 2017.

150. Battaglia R, Palini S, Vento ME,La Ferlita A, Lo Faro MJ, Caroppo E, Borzì P, Falzone L, Barbagallo D, Ragusa M, et al: Identification of extracellular vesicles and characterization of miRNA expression profiles in human blastocoel fluid. Sci Rep 9: 84, 2019.

151. Candido S, Lupo G, Pennisi M, Basile MS, Anfuso CD Petralia MC, Gattuso G, Vivarelli S, Spandidos DA, Libra M, et al: The analysis of miRNA expression profiling datasets reveals inverse microRNA patterns in glioblastoma and Alzheimer's disease. Oncol Rep 42: 911-922, 2019.

152. Falzone L, Romano GL, Salemi R, Bucolo C, Tomasello B, Lupo G, Anfuso CD, Spandidos DA, Libra M and Candido S: Prognostic significance of deregulated microRNAs in uveal melanomas. Mol Med Rep 19: 2599-2610, 2019.

153. Falzone L, Scola L, Zanghì A, Biondi A, Di Cataldo A, Libra $\mathrm{M}$ and Candido S: Integrated analysis of colorectal cancer microRNA datasets: Identification of microRNAs associated with tumor development. Aging (Albany NY) 10: 1000-1014, 2018.

154. Polo A, Crispo A, Cerino P, Falzone L, Candido S, Giudice A, De Petro G, Ciliberto G, Montella M, Budillon A, et al Environment and bladder cancer: Molecular analysis by interaction networks. Oncotarget 8: 65240-65252, 2017.

155. McCubrey JA, Fitzgerald TL, Yang LV, Lertpiriyapong K, Steelman LS, Abrams SL, Montalto G, Cervello M, Neri LM, Cocco L, et al: Roles of GSK-3 and microRNAs on epithelial mesenchymal transition and cancer stem cells. Oncotarget 8 : 14221-14250, 2017.

156. Falzone L, Candido S, Salemi R, Basile MS, Scalisi A, McCubrey JA, Torino F, Signorelli SS, Montella M and Libra M: Computational identification of microRNAs associated to both epithelial to mesenchymal transition and NGAL/MMP-9 pathways in bladder cancer. Oncotarget 7: 72758-72766, 2016.

157. Hafsi S, Candido S, Maestro R, Falzone L, Soua Z, Bonavida B, Spandidos DA and Libra M: Correlation between the overexpression of Yin Yang 1 and the expression levels of miRNAs in Burkitt's lymphoma: A computational study. Oncol Lett 11: 1021-1025, 2016.

158. Dalmasso G, Nguyen HTT, Yan Y, Laroui H, Charania MA, Ayyadurai S, Sitaraman SV and Merlin D: Microbiota modulate host gene expression via microRNAs. PLoS One 6: e19293, 2011.
159. Peck BCE, Mah AT, Pitman WA, Ding S, Lund PK and Sethupathy P: Functional transcriptomics in diverse intestinal epithelial cell types reveals robust microrna sensitivity in intestinal stem cells to microbial status. J Biol Chem 292: 2586-2600, 2017.

160. Yuan C and Subramanian S: MicroRNA mediated tumormicrobiota metabolic interactions in colorectal cancer. DNA Cell Biol 38: 281-285, 2019.

161. Liu S, da Cunha AP, Rezende RM, Cialic R, Wei Z, Bry L, Comstock LE, Gandhi R and Weiner HL: The host shapes the gut microbiota via fecal microrna. Cell Host Microbe 19: 32-43, 2016.

162. Zhang L, Chen T, Yin Y, Zhang CY and Zhang YL: Dietary microRNA-A Novel Functional Component of Food. Adv Nutr 10: 711-721, 2019

163. Teodori L, Petrignani I, Giuliani A, Prattichizzo F, Gurău F, Matacchione G, Olivieri F, Coppari S and Albertini MC: Inflamm-aging microRNAs may integrate signals from food and gut microbiota by modulating common signalling pathways. Mech Ageing Dev 182: 111127, 2019.

164. Lang C, Karunairetnam S, Lo KR, Kralicek AV, Crowhurst RN, Gleave AP, MacDiarmid RM and Ingram JR: Common Variants of the Plant microRNA-168a Exhibit Differing Silencing Efficacy for Human Low-Density Lipoprotein Receptor Adaptor Protein 1 (LDLRAP1). MicroRNA 8: 166-170, 2019.

165. Golan-Gerstl R, Elbaum Shiff Y, Moshayoff V, Schecter D, Leshkowitz D and Reif S: Characterization and biological function of milk-derived miRNAs. Mol Nutr Food Res 61: 1700009, 2017

166. Wagner AE, Piegholdt S, Ferraro M, Pallauf K and Rimbach G: Food derived microRNAs. Food Funct 6: 714-718, 2015.

167. Teng Y, Ren Y, Sayed M, Hu X, Lei C, Kumar A, Hutchins E, Mu J, Deng Z, Luo C, et al: Plant-derived exosomal micrornas shape the gut microbiota. Cell Host Microbe 24: 637-652.e8, 2018.

168. Adami GR, Tangney CC, Tang JL, Zhou Y, Ghaffari S, Naqib A, Sinha S, Green SJ and Schwartz JL: Effects of green tea on miRNA and microbiome of oral epithelium. Sci Rep 8: 5873, 2018

169. Felden B and Gilot D: Modulation of bacterial srnas activity by epigenetic modifications: Inputs from the eukaryotic miRNAs. Genes (Basel) 10: E22, 2018

170. Bloch S, Węgrzyn A, Węgrzyn G and Nejman-Faleńczyk B Small and smaller-sRNAs and microRNAs in the regulation of toxin gene expression in prokaryotic cells: A mini-review. Toxins (Basel) 9: E181, 2017.

171. YuanC,SteerCJandSubramanianS:Host-microRNA-microbiota interactions in colorectal cancer. Genes (Basel) 10: E270, 2019.

172. Miro-Blanch $\mathrm{J}$ and Yanes O: Epigenetic regulation at the interplay between gut microbiota and host metabolism. Front Genet 10: 638, 2019.

173. Patrignani P, Tacconelli S and Bruno A: Gut microbiota, host gene expression, and aging. J Clin Gastroenterol 48 (Suppl 1): S28-S31, 2014.

174. Masotti A: Interplays between gut microbiota and gene expression regulation by miRNAs. Front Cell Infect Microbiol 2: 137,2012

175.Zhao H, Chu M, Huang Z, Yang X, Ran S, Hu B, Zhang C and Liang J: Variations in oral microbiota associated with oral cancer. Sci Rep 7: 11773, 2017.

176. Al-Hebshi NN, Nasher AT, Maryoud MY, Homeida HE, Chen T, Idris AM and Johnson NW: Inflammatory bacteriome featuring Fusobacterium nucleatum and Pseudomonas aeruginosa identified in association with oral squamous cell carcinoma. Sci Rep 7: 1834, 2017.

177. Audirac-Chalifour A, Torres-Poveda K, Bahena-Román M, Téllez-Sosa J, Martínez-Barnetche J, Cortina-Ceballos B, López-Estrada G, Delgado-Romero K, Burguete-García AI, Cantú D, et al: Cervical microbiome and cytokine profile at various stages of cervical cancer: A pilot study. PLoS One 11: e0153274, 2016.

178. Hsieh YY, Tung SY, Pan HY, Yen CW, Xu HW, Lin YJ, Deng YF, Hsu WT, Wu CS and Li C: Increased abundance of Clostridium and Fusobacterium in gastric microbiota of patients with gastric cancer in Taiwan. Sci Rep 8: 158, 2018.

179. Yamamura K, Baba Y, Nakagawa S, Mima K, Miyake K, Nakamura K, Sawayama H, Kinoshita K, Ishimoto $\mathrm{T}$, Iwatsuki M, et al: Human microbiome Fusobacterium nucleatum in esophageal cancer tissue is associated with prognosis. Clin Cancer Res 22: 5574-5581, 2016.

180. Yang CY, Yeh YM, Yu HY, Chin CY, Hsu CW, Liu H, Huang PJ, $\mathrm{Hu} \mathrm{SN}$, Liao CT, Chang KP, et al: Oral microbiota community dynamics associated with oral squamous cell carcinoma staging. Front Microbiol 9: 862, 2018. 
181.Lim Y, Fukuma N, Totsika M, Kenny L, Morrison M and Punyadeera C: The performance of an oral microbiome biomarker panel in predicting oral cavity and oropharyngeal cancers. Front Cell Infect Microbiol 8: 267, 2018.

182. Sasaki M, Yamaura C, Ohara-Nemoto Y, Tajika S, Kodama Y, Ohya T, Harada R and Kimura S: Streptococcus anginosus infection in oral cancer and its infection route. Oral Dis 11: 151-156, 2005.

183. Pushalkar S, Ji X, Li Y, Estilo C, Yegnanarayana R, Singh B, Li X and Saxena D: Comparison of oral microbiota in tumor and non-tumor tissues of patients with oral squamous cell carcinoma. BMC Microbiol 12: 144, 2012.

184. Galvão-Moreira LV and da Cruz MC: Oral microbiome, periodontitis and risk of head and neck cancer. Oral Oncol 53: 17-19, 2016.

185. Shiga K, Tateda M, Saijo S, Hori T, Sato I, Tateno H, Matsuura K, Takasaka T and Miyagi T: Presence of Streptococcus infection in extra-oropharyngeal head and neck squamous cell carcinoma and its implication in carcinogenesis. Oncol Rep 8: 245-248, 2001.

186. Narikiyo M, Tanabe C, Yamada Y, Igaki H, Tachimori Y, Kato H, Muto M, Montesano R, Sakamoto H, Nakajima Y, et al: Frequent and preferential infection of Treponema denticola Streptococcus mitis, and Streptococcus anginosus in esophageal cancers. Cancer Sci 95: 569-574, 2004.

187. Yang SF, Huang HD, Fan WL, Jong YJ, Chen MK, Huang CN, Chuang CY, Kuo YL, Chung WH and Su SC: Compositional and functional variations of oral microbiota associated with the mutational changes in oral cancer. Oral Oncol 77: 1-8, 2018.

188. Kumar M, Kumar A, Nagpal R, Mohania D, Behare P, Verma V, Kumar P, Poddar D, Aggarwal PK, Henry CJ, et al: Cancerpreventing attributes of probiotics: An update. Int J Food Sci Nutr 61: 473-496, 2010.

189. Yu AQ and $\mathrm{Li} \mathrm{L}$ : The potential role of probiotics in cancer prevention and treatment. Nutr Cancer 68: 535-544, 2016.

190. Lee JW, Shin JG, Kim EH, Kang HE, Yim IB, Kim JY, Joo HG and Woo HJ: Immunomodulatory and antitumor effects in vivo by the cytoplasmic fraction of Lactobacillus casei and Bifidobacterium longum. J Vet Sci 5: 41-48, 2004.

191. Ma EL, Choi YJ, Choi J, Pothoulakis C, Rhee SH and Im E: The anticancer effect of probiotic Bacillus polyfermenticus on human colon cancer cells is mediated through ErbB2 and ErbB3 inhibition. Int J Cancer 127: 780-790, 2010.

192. Kim Y, Oh S, Yun HS, Oh S and Kim SH: Cell-bound exopolysaccharide from probiotic bacteria induces autophagic cell death of tumour cells. Lett Appl Microbiol 51: 123-130, 2010.

193. Borowicki A, Michelmann A, Stein K, Scharlau D, Scheu K, Obst U and Glei M: Fermented wheat aleurone enriched with probiotic strains LGG and Bb12 modulates markers of tumor progression in human colon cells. Nutr Cancer 63: 151-160, 2011

194. Stein K, Borowicki A, Scharlau D, Schettler A, Scheu K, Obst U and Glei M: Effects of synbiotic fermentation products on primary chemoprevention in human colon cells. J Nutr Biochem 23: 777-784, 2012.
195. Wan LH, Yao Z, Ni F, Wei M, Zhou Z, Wang HQ, Sun Y and Zhong ZX: Biosynthesis of genipin from gardenoside catalyzed by $\beta$-glucosidase in two-phase medium. CIESC J 65: 3583-3591, 2014.

196. Asoudeh-Fard A, Barzegari A, Dehnad A, Bastani S, Golchin A and Omidi Y: Lactobacillus plantarum induces apoptosis in oral cancer KB cells through upregulation of PTEN and downregulation of MAPK signalling pathways. Bioimpacts 7: 193-198, 2017.

197. Aghazadeh Z, Pouralibaba F and Yari Khosroushahi A: The prophylactic effect of Acetobacter syzygii probiotic species against squamous cell carcinoma. J Dent Res Dent Clin Dent Prospects 11: 208-214, 2017.

198. Orlandi E, Iacovelli NA, Tombolini V, Rancati T, Polimeni A, De Cecco L, Valdagni R and De Felice F: Potential role of microbiome in oncogenesis, outcome prediction and therapeutic targeting for head and neck cancer. Oral Oncol 99: 104453, 2019.

199. Christofi T, Baritaki S, Falzone L, Libra M and Zaravinos A: Current perspectives in cancer immunotherapy. Cancers (Basel) 11: E1472, 2019

200. Guerrero-Preston R, Godoy-Vitorino F, Jedlicka A, RodríguezHilario A, González H, Bondy J, Lawson F, Folawiyo O, Michailidi C, Dziedzic A, et al: 16S rRNA amplicon sequencing identifies microbiota associated with oral cancer, human papilloma virus infection and surgical treatment. Oncotarget 7: 51320-51334, 2016

201. Tuaeva NO, Falzone L, Porozov YB, Nosyrev AE, Trukhan VM, Kovatsi L, Spandidos DA, Drakoulis N, Kalogeraki A, Mamoulakis C, et al: Translational application of circulating DNA in oncology: Review of the last decades achievements. Cells 8: E1251, 2019.

202. Silantyev AS, Falzone L, Libra M, Gurina OI, Kardashova KS, Nikolouzakis TK, Nosyrev AE, Sutton CW, Mitsias PD and Tsatsakis A: Current and future trends on diagnosis and prognosis of glioblastoma: From molecular biology to proteomics. Cells 8: E863, 2019.

203. Ribeiro IP, de Melo JB and Carreira IM: Head and neck cancer: Searching for genomic and epigenetic biomarkers in body fluids - the state of art. Mol Cytogenet 12: 33, 2019.

204. Falzone L, Salomone S and Libra M: Evolution of cancer pharmacological treatments at the turn of the third millennium. Front Pharmacol 9: 1300, 2018.

205. Aas JA, Paster BJ, Stokes LN, Olsen I and Dewhirst FE: Defining the normal bacterial flora of the oral cavity. J Clin Microbiol 43: 5721-5732, 2005.

206. Chattopadhyay I, Verma M and Panda M: Role of oral microbiome signatures in diagnosis and prognosis of oral cancer. Technol Cancer Res Treat 18: 1533033819867354, 2019.

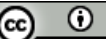

This work is licensed under a Creative Commons Attribution 4.0 International (CC BY 4.0) License. 